\title{
Compensation Regulation Against Victims of Mistakes in The Implementation of Criminal Law in Indonesia
}

\author{
Sugeng Aribowo*, Sri Endah Wahyuningsih"*, Gunarto** \\ * Doctoral Program Faculty of Law, Sultan Agung Islamic University, Semarang, Indonesia \\ ** Faculty of Law, Sultan Agung Islamic University Semarang, Indonesia \\ DOI: 10.29322/IJSRP.12.01.2022.p12134 \\ http://dx.doi.org/10.29322/IJSRP.12.01.2022.p12134
}

\begin{abstract}
The amount of compensation for errors in the application of criminal law in Indonesia in Article 9 paragraph (1) of Government Regulation Number 92 of 2015 concerning the second amendment of Government Regulation Number 27 of 1983 concerning Compensation and Settlement of the Amount of Compensation has not been fair. The purpose of this study is to analyze the implementation of losses to victims of the application of criminal law in Indonesia which is not based on the value of justice. secondary. Primary data was obtained by conducting direct interviews with informants. The secondary data is obtained by conducting a literature study on primary legal materials in the form of legislation, secondary legal materials in the form of books, journals, results of previous research and tertiary legal materials in the form of legal dictionaries and encyclopedias. The data obtained were then analyzed by qualitative descriptive method. The results of the study that the implementation of compensation for victims of misapplication of the law has not been fair, this can be seen by the amount of compensation which is only Rp. 500,000.00. Up to Rp. 100,000,000; The cause of the implementation of compensation for victims of misapplication of the law has not been fair due to weaknesses in terms of legal regulations, difficulty in accessing legal aid for the poor, and the minimal role of the government so that it is clear that the implementation of compensation for victims of misapplication of the law is contrary to the mandate of Pancasila and the Constitution. NRI 1945, so that the implementation of compensation for victims of misapplication of the law has not been able to bring about justice. In the implementation of compensation for victims of misapplication of the law so far, there have been problems in the form of the small value of compensation as referred to in Article 9 paragraph (1) Government Regulation Number 92 of 2015 concerning the second amendment of Government Regulation Number 27 of 1983 concerning Compensation and Compensation Amount disadvantages and complicated mechanisms.
\end{abstract}

Index Terms- Reconstruction, Regulation, Compensation, Victims of Errors, Application of criminal law, Value of Justice.

\section{INTRODUCTION}

$\mathrm{T}$ he life of the Indonesian people applies customary law and religious law, which recognizes deliberation, mutual cooperation, peace which is often called deliberation to reach consensus as contained in the 4th Precept of Pancasila. Therefore, it is appropriate if efforts to develop national criminal law, especially the Criminal Code, are based on the values of Pancasila as the source of all sources of development law in Indonesia, in order to realize a criminal law that is just for both perpetrators, victims and the community [1]. Criminal law in Indonesia currently philosophically prioritizes legal certainty rather than justice and legal benefits because the Indonesian Criminal Code is still a law that follows the classical flow, which adheres to the principle of rigid legality and is actionoriented (daad strafrech). so that criminal sanctions are given to retaliate for the actions of the perpetrators and have not been oriented to people (both perpetrators and victims) [2].

The criminal fine was first discussed by W. J. Leyds in his dissertation entitled De Rechtsgrond der Schadevergoeding voor Preventieve Hechtenis. Meanwhile, in Indonesia, in its development, fines began to be clearly regulated in Government Regulation Number 27 of 1983 concerning the Implementation of the Criminal Procedure Code. However, this Government Regulation has various weaknesses, including:

1) PP No. 27 of 1983 has been far behind, this can be seen with the philosophy of making PP no. 27 of 1983 has not been in accordance with the integrated criminal law system and restoratie justice system;

2) The number of renewals of the authority of law enforcement agencies that are not regulated in PP No. 27 of 1983. This is in line with the opinion of Barda Nawawi Arief. Barda Nawawi's view basically explains that the old regulations have regulated the structure of the judiciary and the public prosecutor's organization but have not regulated the structure of the investigative institution; 3) The amount of compensation in PP No. 27 of 1983 is no longer relevant.

These weaknesses became the basis for the issuance of Government Regulation Number 92 of 2015 concerning the second amendment of Government Regulation Number 27 of 1983 concerning the Implementation of the Criminal Procedure Code on December 8, 2015. Article 9 concerning the amount of compensation stated that: 
a) The amount of compensation based on the reasons as referred to in Article 77 letter b and Article 95 of the Criminal Procedure Code is at least Rp. 500,000.00 (five hundred thousand rupiah) and a maximum of Rp. 100,000,000.00 (one hundred million rupiah).

b) The amount of compensation based on the reasons as referred to in Article 95 of the Criminal Procedure Code which results in serious injury or disability so that one cannot carry out work, the amount of compensation is at least Rp. 25,000,000.00 (twentyfive million rupiah) and a maximum of Rp. 300,000,000.00 (three hundred million rupiah).

c) The amount of compensation based on the reasons as referred to in Article 95 of the Criminal Procedure Code resulting in death, the amount of compensation is at least Rp. 50,000,000.00 (fifty-five million rupiah) and a maximum of Rp. 600,000,000.00 (six hundred million rupiah).

The amount of compensation is Rp. 500,000, - (five hundred thousand rupiah) by the government to victims of misapplication of criminal law by law enforcement is very small when compared to the effort and costs that must be incurred by the victim. This shows how the implementation of Government Regulation Number 92 of 2015 concerning the second amendment of Government Regulation Number 27 of 1983 concerning the Implementation of the Criminal Procedure Code has neglected the value of justice and legal benefits due to the energy and costs incurred as well as losses due to errors in the application of the law. comparable to the compensation of only Rp. $500,000.00$, this will obviously also result in a mismatch of the objectives of the criminal law which should bring about justice for the community as a whole [3].

Based on the explanation above, this study analyzes the implementation of compensation for victims of errors in the application of criminal law in Indonesia.

\section{RESEARCH METHOD}

1) Types of Research Approach

The approach method used in this qualitative legal research is a sociological juridical approach, which is an approach by seeking information through direct interviews with informants empirically first and then proceeding with conducting secondary data research contained in the literature study through theoretical steps.

2) Data Type

Research data in the form of primary data and secondary data. Primary data in the form of literature study of literature related to the object of research consisting of books, laws and regulations and documents from related agencies. The laws and regulations used in this research are the 1945 Constitution of the Republic of Indonesia, the Criminal Code, and Law Number 12 of 2011. Secondary data or library data in the form of primary legal materials, secondary legal materials, and tertiary legal materials. Secondary data is obtained through information or information obtained directly through the field in the form of interviews with policy makers consisting of related bureaucrats, prosecutors, police, actors, and academics. Tertiary data in the form of a large Indonesian language dictionary, scientific dictionaries, legal dictionaries, and literature obtained through the internet.

3) Data Collection Techniques

The data collection techniques carried out are as follows:

a. Literature review

The data collection technique in this research will first be a literature study by conducting a normative legal study in the analysis process of policy making related to the issue of implementing the value of justice and the value of legal certainty in law enforcement.

b. Observation

After conducting a literature study in this study, field observations were then carried out to obtain some related information regarding the issue of implementing the value of justice and the value of legal certainty in law enforcement., actions, events or events, time, and perceptions.

c. Deep interview

After conducting a literature study and direct observation in the field, the researcher will conduct in-depth interviews where in this interview process there will be a dialogue interaction process between the researcher and the informants. Interviews are the main instrument for obtaining field data based on the results of interviews with key informants. The main informants were determined based on the sample or purposive sampling according to the needs of this research.

4) Data Analysis Method

The data obtained in this study were then selected and arranged systematically for further analysis and presentation using qualitative analysis methods. The logic of thinking used in this research is the logic of deductive thinking, where this research departs from things (rules/norms/theories/rules of law) that are general to things that are specific (particular).

\section{DISCUSSION AND FINDINGS}

The function and purpose of the criminal procedure law or the Criminal Procedure Code (KUHAP) is intended to protect citizens from arbitrary actions by law enforcement officials. On the other hand, the law gives authority to the state and government through its law enforcement officers to take actions that can violate the human rights of its citizens who violate the law, one form of protection is the provision of compensation and rehabilitation to victims of wrongful arrests [4]. 
The amount of compensation and the process of providing compensation to victims in 1983 are certainly not in accordance with the current state of development in Indonesia. So it is necessary to adjust the amount of compensation so that it does not cause a sense of injustice to the victims of compensation applicants, based on the above considerations, Government Regulation Number 92 of 2015 concerning the Second Amendment to Government Regulation Number 27 of 1983 concerning the Implementation of the Criminal Procedure Code is issued., in order to fulfill the sense of justice, balance, benefits, legal certainty, and humanity for victims. Some of the substances that have been changed include the amount of compensation and the process of paying compensation to the applicant for compensation [5].

Compensation is a right granted by the state to victims who feel aggrieved because they are arrested, detained, prosecuted and tried or subjected to other actions, without any reason based on law or because of an error regarding the person or the law applied by law enforcement. The issuance of Government Regulation Number 92 of 2015 concerning the Second Amendment to Government Regulation Number 27 of 1983 concerning the Implementation of the Criminal Procedure Code, is expected to encourage law enforcement officers to be careful in conducting investigations in the context of arresting and detaining someone [6].

In the provision of wrongful arrest, in addition to the Government Regulation of the Republic of Indonesia Number 92 of 2015 concerning the Second Amendment to Government Regulation Number 27 of 1983 concerning the Implementation of the Criminal Procedure Code, in practice, wrongful arrest includes acts of violation by the Indonesian National Police as regulated in Government Regulation Number 1 of 2003 concerning Dismissal of Police Members [7].

A person who becomes a victim by an investigator can demand compensation for the investigator's mistake, as explained in Article 1 paragraph 23, the Criminal Procedure Code. prosecuted or tried without reason based on the law or the law applied according to the method regulated in this law. The case of wrongful arrest is a case of systematic human rights violations and is a very serious crime. Therefore, the handling must be extraordinary. Victims can also sue law enforcers who wrongly punish criminally and civilly, for example because of persecution in accordance with Article 351 of the Criminal Code and Article 1365 of the Civil Code regarding unlawful acts [8].

In Government Regulation No. 92 of 2015 concerning the Second Amendment to Government Regulation No. 27 of 1983 concerning the Implementation of the Criminal Procedure Code, regulates the grace period for submitting applications for compensation which is regulated in Article 1 of Government Regulation no. 92 of 2015 which reads as follows: The provisions of Article 7 PP No. 27 of 1983 amended so that it reads as follows:

1. The claim for compensation as referred to in Article 95 of the Criminal Procedure Code can only be filed within a maximum period of 3 (three) months from the date on which the excerpt or copy of the court's decision has obtained legal force which is still accepted.

2. In the event that the claim for compensation is filed against a case that was terminated at the level of investigation or at the level of prosecution as referred to in Article 77 letter b of the Criminal Procedure Code, then within a period of 3 (three) months calculated from the date of notification of the pretrial determination.

The explanation of the amendment to Article 7 of PP No. 27 of 1983 states that the limitation of the period of compensation is intended so that the settlement is not too long so as to guarantee legal certainty, then the right to apply for compensation has expired, in other words, it cannot be submitted again [9].

Article 1 point 3 of PP No. 92 of 2015 concerning amendments to Article 10 of PP No. 27 of 1983 explains that the excerpt of the decision or determination of compensation which is the basis for the judge's consideration, must be given to the applicant within 3 (three) days after the decision is pronounced. After that, the decision or determination must be given to the public prosecutor, investigator, and minister who carries out government affairs in the financial sector. When this government regulation comes into force, the provisions of the laws and regulations which are the implementation of this government regulation which regulates compensation must be adjusted to this government regulation within a maximum period of 6 (six) months from the date this government regulation is promulgated [10]. In essence, the application for compensation is distinguished as follows:

a. Claims for compensation whose cases were not submitted to the Court (Article 95 paragraph 2 of the Criminal Procedure Code).

b. Claims for compensation whose cases are submitted to court (Article 92 paragraph 1 in conjunction with paragraph 3, paragraph 4 and paragraph 5 of the Criminal Procedure Code).

Claims for compensation whose cases are not submitted to the Court either because they are not criminal acts, while the suspect has been subjected to coercive measures in the form of arrests, detentions and other unlawful acts, in this case the pretrial examines and decides on the claim for compensation [11].

The examination of compensation is regulated in article 95 paragraph (5) of the Criminal Procedure Code which reads as follows "The examination of compensation as referred to in paragraph (4) follows the pretrial procedure". The pretrial decision is in the form of a determination and subsequently the pretrial decision cannot be appealed (Article 83 paragraph 1 of the Criminal Procedure Code), with the exception of the decision that stipulates the invalidity of a termination of an investigation or prosecution, for which a final decision can be requested to the High Court in the relevant jurisdiction. (Article 83 paragraph 2). Thus, according to Article 82 of the Criminal Procedure Code, the Chief Justice of the Court within a period of 3 (three) days after receiving the application/demand for compensation, the appointed judge shall determine the day of the trial. The appointment of judges by the head of the court is carried out by taking into account Article 95 paragraph (4) of the Criminal Procedure Code which reads as follows "to examine and decide the case for claims for compensation as referred to in paragraph (1) the chairman of the court as far as possible appoints the same judge who has tried the criminal case concerned" [12]. 
The formal form of the application or claim for compensation is not regulated in the Criminal Procedure Code or Government Regulation No. 27 of 1983, only submitted to the Court which is authorized to hear the case in question. Accordingly, the application for compensation shall contain:

a) Identity of the applicant;

b) The case of the position that causes the compensation is requested, by attaching the evidence.

c) Details of the amount of compensation requested.

The examination of the compensation case must have been decided within 7 (seven) days in accordance with the sound of Article 82 paragraph (1) letter $\mathrm{c}$ of the Criminal Procedure Code which reads as follows "The examination is carried out quickly and no later than seven days the judge must have rendered his decision".

The decision on the request for compensation is regulated by Article 96 of the Criminal Procedure Code which reads as follows:

a) The decision on the award of compensation is in the form of a determination.

b) The stipulation as referred to in paragraph (1) contains in full all the things considered as reasons for the decision.

This is detailed by Article 8 and PP 27 of 1983 which reads as follows:

a) Compensation can be given on the basis of the judge's consideration

b) When the judge grants or rejects the claim for compensation, the reasons for granting or rejecting the claim for compensation are included in the stipulation of Article 96 of the Criminal Procedure Code and Article 8 of PP 27 of 1983 in formulating a request/demand for compensation, it is necessary to pay attention to in order to submit appropriate reasons accompanied by evidence so that the Judge does not experience difficulties in his considerations which are included in the stipulation.

It is possible that the judge will hear the parties mentioned in the letter of request/demand for compensation, but if the same Judge who has tried the criminal case in question has examined the request for compensation, then he already knows and understands the issue of the case, and can examine the original case file, the judge can immediately issue a determination containing considerations. Furthermore, after being decided, the judge carries out the things regulated in Article 10 of PP No. 27 of 1983 which has been amended according to PP No. 92 of 2015 which reads as follows:

a) An excerpt of the determination of compensation as referred to in Article 8 shall be given to the applicant within 3 (three) days after the decision is pronounced.

b) A copy of the decision or stipulation of compensation as referred to in paragraph (1) shall be given to the Public Prosecutor, Investigator and the Minister who carries out Government affairs in the financial sector.

Merger of claims for compensation in the Criminal Procedure Code is regulated in Article 98 to Article 101 of the Criminal Procedure Code. The emergence of a claim for compensation in a civil manner is usually caused by a criminal act based on Article 1365 K.U.H. Civil. Usually compensation based on this article is carried out after a criminal decision has permanent legal force. But now this can be done in conjunction with the criminal process, based on the provisions of the Criminal Procedure Code [13].

Article 98 of the Criminal Procedure Code shows that the criminal procedure law does not only pay attention to the rights of the perpetrators of criminal acts, but also the rights of people who suffer "material" losses due to the commission of a crime. The merger referred to here is the examination of a lawsuit for compensation of a civil nature with an ongoing criminal case. It is clear that the criminal case is the basis of the civil suit and is decided at the same time as the criminal case [11].

Regarding the conditions for merging the claim for compensation, it is regulated in Article 98 paragraph (2) of the Criminal Procedure Code, namely no later than before the public prosecutor submits a criminal charge and in the event that the public prosecutor is not present, the request is submitted no later than before the judge makes a decision. In the event that the public prosecutor is not present, the public prosecutor is not present in this criminal case, because the case is decided by a quick examination (Article 205 of the Criminal Procedure Code and so on) [14].

As a conclusion from Article 98 of the Criminal Procedure Code, the provisions indicate:

a) There is a request from the injured party.

b) There is really a loss resulting from the actions/actions of the defendant.

c) This request for compensation can only be submitted no later than before the judge makes a decision.

After these conditions are met, then Article 99 of the Criminal Procedure Code requires the District Court to consider its authority to adjudicate the lawsuit, namely the truth of the basis of the lawsuit and the law for reimbursement of costs that have been incurred by the aggrieved party. Except in the event that the District Court declares that it is not authorized, in other words the lawsuit is declared not accepted, then the judge's decision only contains the determination of costs that have been incurred by the aggrieved party. This means that the claim for compensation is not granted, but the costs that have been incurred by the injured party are determined to obtain a compensation, the amount of which depends on the evidence of the expenditure which is submitted before the Court. Decisions regarding compensation will automatically obtain permanent legal force, if the criminal decision obtains a permanent decision. Article 100 of the Criminal Procedure Code states that:

1. If there is a merger between a civil case and a criminal case, then the merger will automatically take place at the appeal level examination.

2. If a request for an appeal is not filed against a criminal case, the request for an appeal regarding the decision for compensation is not permitted.

This explains that the incorporation of the lawsuit in the criminal case is intended so that the lawsuit can be examined and decided at the same time as the criminal case, so that the procedure for litigation cannot be carried out individually [15]. 
This compensation arrangement is regulated in the amendment to Article 9 point 1 of PP No. 27 of 1983 , in PP No. 92 of 2015 it is stated that "The amount of compensation based on the reasons as referred to in Article 77 letter b and Article 95 of the Criminal Procedure Code is at least Rp. 500,000.00 (five hundred thousand rupiah) and a maximum of Rp. 100,000,000.00 (one hundred million rupiah)." Then Article 9 point 2 states that "The amount of compensation based on the reasons as referred to in Article 95 of the Criminal Procedure Code which results in serious injury or disability so that you cannot do work, the amount of loss is at least Rp. 25,000,000.00 (twentyfive million rupiah) and a maximum of Rp. 300,000,000.00 (three hundred million rupiah)" [16].

If the criminal act results in the death of a person, the amount of compensation is regulated in the amendment to Article 9 point 3 PP No. 27 of 1983, which states that "The amount of compensation for losses is based on the reasons as referred to in Article 95 of the Criminal Procedure Code which results in death, the amount of compensation is at most a little Rp. 50,000,000.00 (fifty million rupiah) and a maximum of Rp. 600,000,000.00 (six hundred million rupiah)." The amount of compensation for the object or goods requested by a third party with an interest and/or witness to the victim is not regulated in PP No. 27/1983; this depends on a case by case basis, taking into account the differences in the methods taken according to the procedure specified in Article 99 paragraph (2) of the Criminal Procedure Code which essentially states that, "if the District Court does not have the authority to adjudicate the merger of cases of compensation claims, the judge's decision shall be only contains the legal stipulation of reimbursement of costs that have been incurred by the aggrieved party" [17].

Confiscated objects consist of objects that can be returned first to interested parties and also confiscated objects that cannot be returned. The confiscated objects of this type can also be decided by a judge with a dictum to be confiscated/confiscated for the state, to be destroyed or damaged until they can no longer be used. And whoever owns the confiscated objects cannot claim compensation [1].

The consequences if a case is set aside for the public interest or the case is closed for the sake of law, there will also be the possibility of confiscated objects that can be returned and which cannot be returned because:

1. The item is included in the prohibited or prohibited category (e.g. narcotics)

2. The goods are obtained from a criminal act

3. The goods are made to commit a criminal act (e.g. tools to make counterfeit money, ammunition, etc.).

After the decision on the compensation case for victims of wrongful arrest, procedures are needed through several agencies as stipulated in Article 10 of Government Regulation no. 27 of 1983 concerning the Implementation of the Criminal Procedure Code (Later amended by Government Regulation No. 92 of 2015 concerning Amendments to Government Regulation No. 27 of 1983 concerning the Implementation of the Criminal Procedure Code), as well as the rules outlined in the Decree of the Minister of Finance of the Republic of Indonesia No. 983/KMK.01/1983. More details will be described as follows:

1. An excerpt of the decision or determination is given to the applicant within 3 (three) days after the decision is pronounced. The district court provides an excerpt of a decision or determination of granting a request for compensation to an interested party. This quotation is given within 3 (three) days from the date the decision is rendered. In giving the excerpt of the determination or decision on compensation to the applicant, it has not yet entered the stage of implementing the payment, so it is only a notification to him about the grant of the request for compensation. The excerpt of the determination is also given to the Public Prosecutor, investigator and director general of the State Treasury Office (hereinafter abbreviated as KPN) local.

2. The Chairman of the District Court submits an application for provision and after there is a determination or decision to grant the request for compensation, the Chairman of the District Court who has an active role in requesting the implementation of the payment, is not the interested party. The head of the court authorized to request payment. This is confirmed in Article 2 of the Decision of the Minister of Finance in the following manner:

a. The head of the local District Court proposes to provide funds to the Minister of Justice through the Secretary General of the Ministry of Justice.

b. Attach the determination of compensation in the application for the provision of funds.

c. The Minister of Justice through the Secretary General of Justice submits a request for the issuance of an Authorization Decree (hereinafter abbreviated as SKO) to the Minister of Finance through the Director General of Budget.

This is confirmed in Article 2 paragraph (2). With the submission of a request for provision of funds by the Head of the District Court to the Minister of Justice based on the request for submission, the Secretary General of the Ministry of Justice:

a. Propose the issuance of SKO to the director general of budget,

b. The request for the issuance of the SKO is submitted by the Secretary General of the Ministry of Justice every quarter or whenever necessary

c. Director General of Budget Issues SKO

Based on the request for issuance of the SKO from the Secretary General of the Ministry of Justice, the Director General of Budget issues the SKO at the expense of the payment and calculation of routine state budget [18].

1. The original SKO is submitted to the rightful After the SKO is received by the entitled, then based on the SKO the applicant immediately submits a request for payment as stipulated in Article 3 of the Decree of the Minister of Finance No. 983/KMK.01/1983.

2. Applicant submits payment to local KPN:

a. Payment requests are made through the Head of the District Court.

b. The Head of the District Court submits a request for payment to the KPN by attaching:

- $\quad$ Authority Decree (SKO)

- Original and a copy or photocopy of the stipulation quotation. 
Letter of request for payment to KPN through the Head of the District Court, the applicant attaches the SKO he received. Likewise, a copy or photocopy of an excerpt of the determination of compensation is also attached to the request. Then the Head of the District Court completes the attachment with the original and a copy of the determination [19].

a. The Head of the District Court forwards the request for payment to the KPN. The request for payment is submitted by the entitled party to the KPN, through the Head of the District Court. Those who are entitled cannot directly submit a payment request to the KPN. In forwarding the request for payment, the Head of the District Court must include a Letter of Request for Payment (hereinafter abbreviated as SPP).

b. Based on the SKO and SPP, KPN issues a Payment Order (hereinafter abbreviated as SPM) to those who are entitled.

If the KPN has received a payment request from the Head of the District Court, and it turns out that all attachments are complete, then based on the SKO and SPP, the KPN issues the SPM in accordance with the provisions of Article 4 paragraph (1) of the Decree of the Minister of Finance No. 983/KMK.01/1983. If the KPN has made the payment of compensation:

KPN affixes a stamp of payment in the original stipulation excerpt, the original stamped stipulation is returned to the Head of the District Court. The problem as he has explained above is also contrary to progressive legal thinking which requires real efforts to change quickly, make fundamental reversals in legal theory and practice, and make various breakthroughs. The liberation is based on the principle that the law is for humans and not the other way around and the law does not exist for itself, but for something broader, namely for human dignity, happiness, welfare, and human glory.

The understanding as stated by Satjipto Rahardjo means that progressive law is a series of radical actions, by changing the legal system (including changing legal regulations if necessary) so that the law is more useful, especially in raising self-esteem and ensuring human happiness and welfare. In simpler terms, progressive law is a law that makes liberation, both in the way of thinking and acting in law, so that it is able to let the law flow only to complete its task of serving humans and humanity. So there is no engineering or partiality in enforcing the law. Because according to him, the law aims to create justice and prosperity for all people [20].

The progressive law paradigm that was initiated by Satjipto Rahardjo is a phenomenal idea aimed at law enforcement officials, especially the judge so that they do not fall into the trap of legal positivism which has given many injustices to yustisiaben (justice seekers) in enforcing the law because law enforcement is a series of a process to challenge values, ideas, ideals that are quite abstract which are the goals of law. The purpose of the law itself is to be able to initiate moral values such as justice and truth. The values must be realized in real reality [21].

Satjipto Rahardjo also tries to highlight the above conditions into the situation of the social sciences, including law, although it is not as dramatic as in physics, but basically there has been a phenomenal change in the laws that are formulated in sentences from simple to complex and from complex ones. -box into a single unit. This is what he calls a holistic view of science (law). This holistic view provides a visionary awareness that something in a certain order has parts that are interrelated either with other parts or with the whole. The implementation of compensation in cases of misapplication of the law so far has several kinds of shortcomings, including:

a. Implementing a court decision on a claim for compensation due to being arrested, detained, prosecuted and tried or subjected to other actions, without any reason based on law or because of an error regarding the person or because of a mistake in applying the law which still has to go through a complicated and lengthy application to the Ministry of Finance. , in fact it is not uncommon for it to be difficult to be approved by the Ministry of Finance;

b. In the event that the amount of compensation can be given at least Rp. 500.000, - (five hundred thousand rupiahs) this is considering that there is a minimum limit of compensation for being arrested, detained, prosecuted and tried or subjected to other actions, without any reason based on law or because of an error regarding the person or due to incorrect application of the law. Rp. 500,000, - (five hundred thousand rupiah)

c. There is no clear parameter or reference in terms of what a person can propose to calculate the value of the loss due to an error in the case of being arrested, detained, prosecuted and tried or subject to other actions, without any reason based on law or because of a mistake regarding the person or because wrong in applying the law.

d. Whether or not a victim can be compensated for a wrongful arrest is based on the logic and belief of the judge who is often unable to bring about justice.

That because the value of at least compensation for victims of errors in the application of the law is still too low, namely Rp. 500.000, (five hundred thousand rupiah) as regulated in Article 9 paragraph (1) Government Regulation Number 92 of 2015 concerning the Second Amendment to Government Regulation Number 27 of 1983 concerning the Implementation of the Criminal Procedure Code, this will clearly make law itself is not capable of realizing justice and in the end the laws that are made will only result in the inability of the state to recover the losses of victims of misapplication of the law so far. This situation is clearly contrary to the progressive legal idea which wants quality law to serve and bring the people to prosperity and happiness as described above [5].

\section{CONCLUSION}

1. The regulation of compensation for victims of misapplication of criminal law has so far had problems in the form of a small amount of compensation as referred to in Article 9 letter a of Government Regulation Number 92 of 2015 concerning the second amendment of Government Regulation Number 27 of 1983 concerning the Implementation of the Code of Law Criminal Procedures and compensation mechanisms are still very complicated.

2. Weaknesses in the implementation of compensation for victims of misapplication of criminal law in the form of the provisions of Article 9 letter a of Government Regulation Number 92 of 2015 concerning the second amendment of Government Regulation

This publication is licensed under Creative Commons Attribution CC BY.

http://dx.doi.org/10.29322/IJSRP.12.01.2022.p12134

WWW.ijsrp.org 
Number 27 of 1983 concerning the Implementation of the Criminal Procedure Code, the implementation mechanism is still complicated so that it is unfair and the lack of access to legal assistance for the victims and the lack of information and the role of the government regarding the mechanism for implementing compensation for victims of misapplication of the law.

\section{REFERENCES}

[1] D. Sudaryanti, E. G. Sukoharsono, Z. Baridwan, and A. D. Mulawarman, "Critical Analysis on Accounting Information Based On Pancasila Value," Procedia Soc. Behav. Sci., vol. 172, pp. 533-539, 2015.

[2] I. K. Seregig, T. Suryanto, B. Hartono, E. Rivai, and E. Prasetyawati, "Preventing the acts of corruption through legal community education," J. Soc. Stud. Educ. Res., vol. 9, no. 2, pp. 138-159, 2018.

[3] S. E. Wahyuningsih, N. Adi, and M. Iksan, "The role of scientific testimony in the process of investigation of crime in Indonesia," pp. 97-103, 2018.

[4] S. E. Wahyuningsih, A. Indah, and M. Iksan, "The implementation of restorative justice to children as perpetrator in criminal investigation in Indonesia," Test Eng. Manag., vol. 83, no. 2746, pp. 2746-2752, 2020.

[5] N. Satrio and F. Faisal, "Hak Saksi Dan Korban Tindak Pidana Kasus Tertentu Dalam Perlindungan Saksi Dan Korban Perspektif Equality Before the Law," Cepalo, vol. 5, no. 1, pp. 1-10, 2021.

[6] H. J. Albrecht and M. Kilchling, "Victims of terrorism policies: Should victims of terrorism be treated differently?," A War Terror. Eur. Stance a New Threat. Chang. Laws Hum. Rights Implic., pp. 221-241, 2010.

[7] C. M. Donner, J. Maskaly, and K. N. Thompson, "Self-control and the police code of silence : Examining the unwillingness to report fellow o ffi cers ' misbehavior among a multi-agency sample of police recruits," J. Crim. Justice, vol. 56, no. May 2017, pp. 11-19, 2018.

[8] B. Hine and A. Murphy, "Journal of Criminal Justice The impact of victim-perpetrator relationship , reputation and initial point of resistance on of fi cers " responsibility and authenticity ratings towards hypothetical rape cases," J. Crim. Justice, vol. 49, pp. 1-13, 2017.

[9] B. . K. R. Aswandi, "Negara Hukum Dan Demokrasi Pancasila Dalam Kaitannya Dengan Hak," J. Pembang. Huk. Indones., vol. 1, no. 1, pp. $128-145,2019$.

[10] A. Alfada, "The destructive effect of corruption on economic growth in Indonesia: A threshold model," Heliyon, vol. 5, no. 10, p. e02649, 2019.

[11] R. A. Wibowo, "When anti-corruption norms lead to undesirable results: learning from the Indonesian experience," Crime, Law Soc. Chang., vol. 70, no. 3, pp. 383-396, 2018.

[12] A. Ismayawati, "Pancasila sebagai Dasar Pembangunan Hukum Di Indonesia," YUDISIA J. Pemikir. Huk. dan Huk. Islam, vol. 8, no. 1, p. 53, 2018.

[13] H. Abdul-Rahman, C. Wang, L. C. Wood, and S. F. Low, "Negative impact induced by foreign workers: Evidence in Malaysian construction sector," Habitat Int., vol. 36, no. 4, pp. 433-443, 2012.

[14] E. Erfandi, "Implementasi Nilai-Nilai Pancasila Dalam Pembangunan Sistem Hukum Pidana Di Indonesia," J. Ilm. Pendidik. Pancasila dan Kewarganegaraan, vol. 1, no. 1, pp. 23-32, 2016.

[15] A. Matsukawa and S. Tatsuki, "International Journal of Law , Crime and Justice Crime prevention through community empowerment : An empirical study of social capital in Kyoto , Japan," Int. J. Law Crime Justice., no. xxxx, pp. 1-13, 2018.

[16] M. D. Kristiana, "POLITICS OF L AW ON SCHOOL DAYS POLICY : LEGAL EFORM ON I NDONESIAN E DUCATION," vol. 1, no. 23, pp. 5-24, 2020.

[17] A. Ahmed, "International Law of the Sea: An Overlook and Case Study," Beijing Law Rev., vol. 08, no. 01, pp. $21-40,2017$.

[18] I. A. Maerani, "Implementasi Ide Keseimbangan Dalam Pembangunan Hukum Pidana Indonesia Berbasis Nilai-Nilai Pancasila," J. Pembaharuan Huk., vol. 11, no. 2, pp. 329-338, 2015.

[19] S. E. Wahyuningsih and M. Sholeh, "Judge's Considerations Analysis toward Perpetrators of Criminal Acts of Sexual Violence to Underage Children in Demak District Court Reviewed with Law Number 35 Year 2014 about Children Protection,” vol. IV, no. 35, pp. 346-352, 2017.

[20] Satjipto Rahardjo, Hukum dalam Jagat Ketertiban. 2006.

[21] R. U. Anshar and J. Setiyono, "Tugas dan Fungsi Polisi Sebagai Penegak Hukum dalam Perspektif Pancasila," J. Pembang. Huk. Indones., vol. 2, no. 3, pp. 359$372,2020$.

\section{AUTHORS}

First Author - Sugeng Aribowo, Doctoral Program Faculty of Law, Sultan Agung Islamic University Indonesia, sz.aribowo@gmail.com.

Second Author - Sri Endah Wahyuningsih, Faculty of Law, Sultan Agung Islamic University Indonesia, endah.w@unissula.ac.id. Third Author - Gunarto, Faculty of Law, Sultan Agung Islamic University Indonesia, gunartowr2@ yahoo.com.

Correspondence Author - Sri Endah Wahyuningsih, Faculty of Law, Sultan Agung Islamic University Indonesia, endah.w@unissula.ac.id. Phone +62 81326472128 